\title{
6-Hydroxy-2-methylbenzofuran-4-carboxylic Acid
}

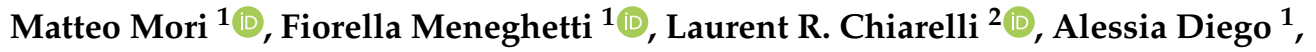 \\ Donatella Nava ${ }^{1}$, Arianna Gelain ${ }^{1}$, Giulia Cazzaniga ${ }^{1}$, Stefania Villa ${ }^{1}$ D and Elena Pini ${ }^{1, *(D)}$ \\ 1 Department of Pharmaceutical Sciences, University of Milan, via L. Mangiagalli 25, 20133 Milano, Italy; \\ matteo.mori@unimi.it (M.M.); fiorella.meneghetti@unimi.it (F.M.); alessia.diego1@gmail.com (A.D.); \\ donatella.nava@unimi.it (D.N.); arianna.gelain@unimi.it (A.G.); giulia.cazzaniga4@studenti.unimi.it (G.C.); \\ stefania.villa@unimi.it (S.V.) \\ 2 Department of Biology and Biotechnology "Lazzaro Spallanzani", University of Pavia, via A. Ferrata 9, \\ 27100 Pavia, Italy; laurent.chiarelli@unipv.it \\ * Correspondence: elena.pini@unimi.it; Tel.: +39-02-503-14606
}

Received: 26 May 2020; Accepted: 15 June 2020; Published: 18 June 2020

\begin{abstract}
Hydroxy-2-methylbenzofuran-4-carboxylic acid was synthesized in two steps, starting from 3,5-dihydroxybenzoate. The product was obtained through a direct thermal one-pot cyclization with propargyl bromide, followed by a base-catalyzed hydrolysis. Its molecular structure was elucidated by means of mono- and bidimensional NMR techniques, ESI-MS, FT-IR and single-crystal X-ray diffraction.
\end{abstract}

Keywords: 6-hydroxy-2-methylbenzofuran-4-carboxylic acid methyl ester; 6-hydroxy-2methylbenzofuran-4-carboxylic acid; COSY; NOESY; HSQC; HMBC; XRD

\section{Introduction}

Tuberculosis (TB) is a contagious and virulent disease, mainly caused by the pathogen Mycobacterium tuberculosis (Mtb); despite having afflicted mankind for centuries, it is still responsible for thousands of deaths in developed and developing countries [1]. The available treatments are outdated, and their use is characterized by significant drawbacks. The approved regimens require the administration of four or more drugs for a considerably long time; moreover, the adverse effects contribute to lowering patient compliance, thus favoring the emergence of drug-resistant Mtb strains [2]. For the past 40 years, the scientific community has been working on two fronts-investigating new compounds acting on known pathways [3] and exploring several new mycobacterial targets-for the development of improved therapeutic strategies [4,5]. Furthermore, efforts have been directed towards the investigation of novel formulations for established drugs, to reduce their side effects and enhance their biopharmaceutical performances [6]. In the last few years, the still-worrying diffusion of TB has prompted political forces around the world to step up their commitment to the fight against the disease, with the organization of the first UN high-level meeting (HLM) on TB, which took place on 26 September 2018 [1].

In recent years, our attention has been turned to the identification of new inhibitors of the salicylate synthase MbtI, an essential, mycobacterium-specific enzyme involved in iron acquisition [7-10]. In this context, the chromanone nucleus caught our attention: new compounds bearing the chromane scaffold were synthetized [11], and their biological evaluation allowed the identification of I (Figure 1) as a novel candidate inhibitor, endowed with a promising activity against $\mathrm{MbtI}\left(\mathrm{IC}_{50}=55 \mu \mathrm{M}\right)$.

With the purpose of synthesizing structurally simplified analogs of compound I that were devoid of the carbonyl function at position 4 and of the methyl group in 2, we unexpectedly isolated a new benzofuran derivative (1), which was submitted to a complete chemical characterization and tested against MbtI. 


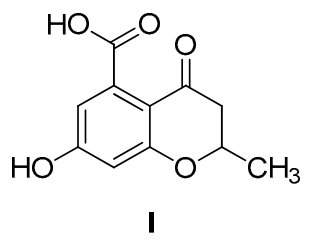

Figure 1. 7-Hydroxy-2-methyl-4-oxo-3,4-dihydro-2H-benzopyran-5-carboxylic acid (I).

\section{Results and Discussion}

6-Hydroxy-2-methylbenzofuran-4-carboxylic acid (1) was synthesized by a two-step reaction (Scheme 1). The commercially available methyl 3,5-dihydroxybenzoate was reacted with propargyl bromide, copper iodide, potassium iodide and potassium carbonate, through a direct thermal intramolecular cyclization. Under these conditions, the phenyl propargyl ether gave a Claisen rearrangement [12,13], ultimately leading to the formation of the 2-methylbenzofuran derivative, which was then hydrolyzed to the corresponding acid under basic conditions.

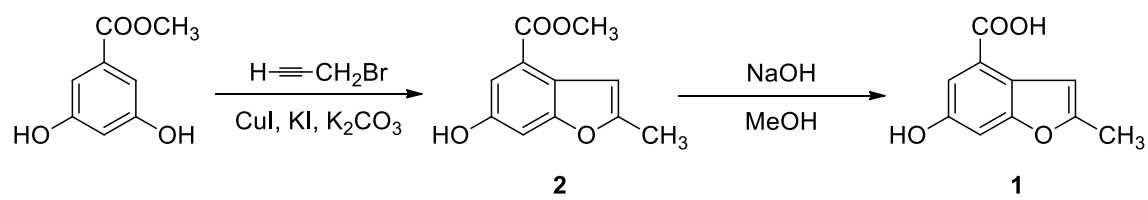

Scheme 1. Synthesis of 6-hydroxy-2-methylbenzofuran-4-carboxylic acid (1).

Compounds 1 and $\mathbf{2}$ were characterized by means of various spectroscopic and spectrometric methods, including mono- and bidimensional NMR, FT-IR and ESI-MS. The structure elucidation of compound 2 was supported by a COSY experiment, which evidenced a correlation between the methyl group at position 2 and the hydrogen in 3. Furthermore, the NOESY spectrum showed a correlation between the hydroxyl function and hydrogens 5-7, and between the methyl of $\mathrm{COOCH}_{3}$ and hydrogens 3-5.

Single-crystal X-ray diffraction was employed to determine the molecular structure of $\mathbf{1}$; its ORTEP [14] representation is reported in Figure 2. The compound crystallized in the triclinic P-1 space group: the asymmetric unit (ASU) accommodates one molecule, with the alcoholic hydrogen split over two positions with a 0.5 occupancy.

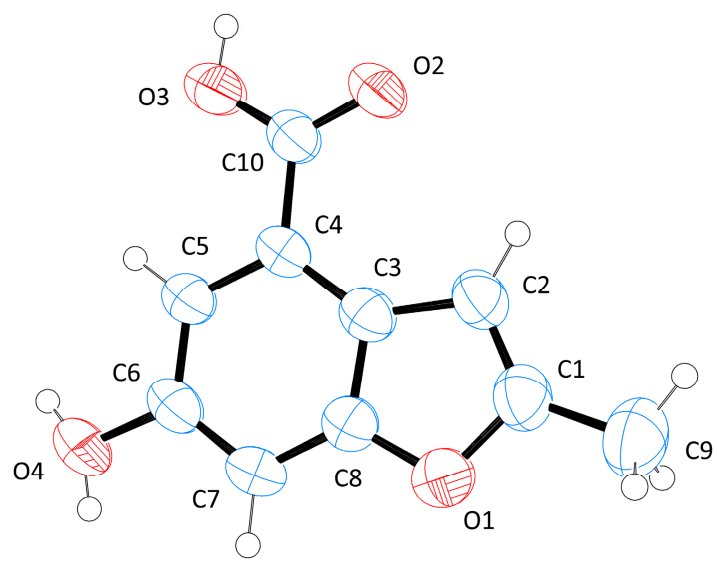

Figure 2. ORTEP plot of $\mathbf{1}$, with the arbitrary atom numbering (ellipsoids are at $40 \%$ probability and $\mathrm{H}$ atoms are represented as spheres of arbitrary radii).

The arrangement of the hydroxyl group can be explained by examining the crystal packing, which shows chains of dimers developing along the $c$ axis (Figure 3). Such dimers are interconnected by a $\mathrm{H}$-bond, formed between $\mathrm{O} 4$ and the hydroxyl hydrogen of two adjacent molecules. This linkage 
justifies the double orientation of the $\mathrm{OH}$; in the donor molecule, the hydrogen (H42) points outward, towards the next dimer, while in the acceptor molecule, the hydrogen (H41) turns inward, towards the other monomer. The two monomers, related by a point of inversion, interact through two equivalent H-bonds, established between the hydrogen and the oxygen of the carboxylic moieties. The aromatic nature of the compound confers rigidity and planarity to the structure. As a consequence, the packing is further stabilized by parallel-displaced $\pi-\pi$ stacking interactions between the heteroaromatic rings, along the $a$ axis. These stacked chains are 3.875(1) $\AA$ apart, as calculated from the ring centroids.

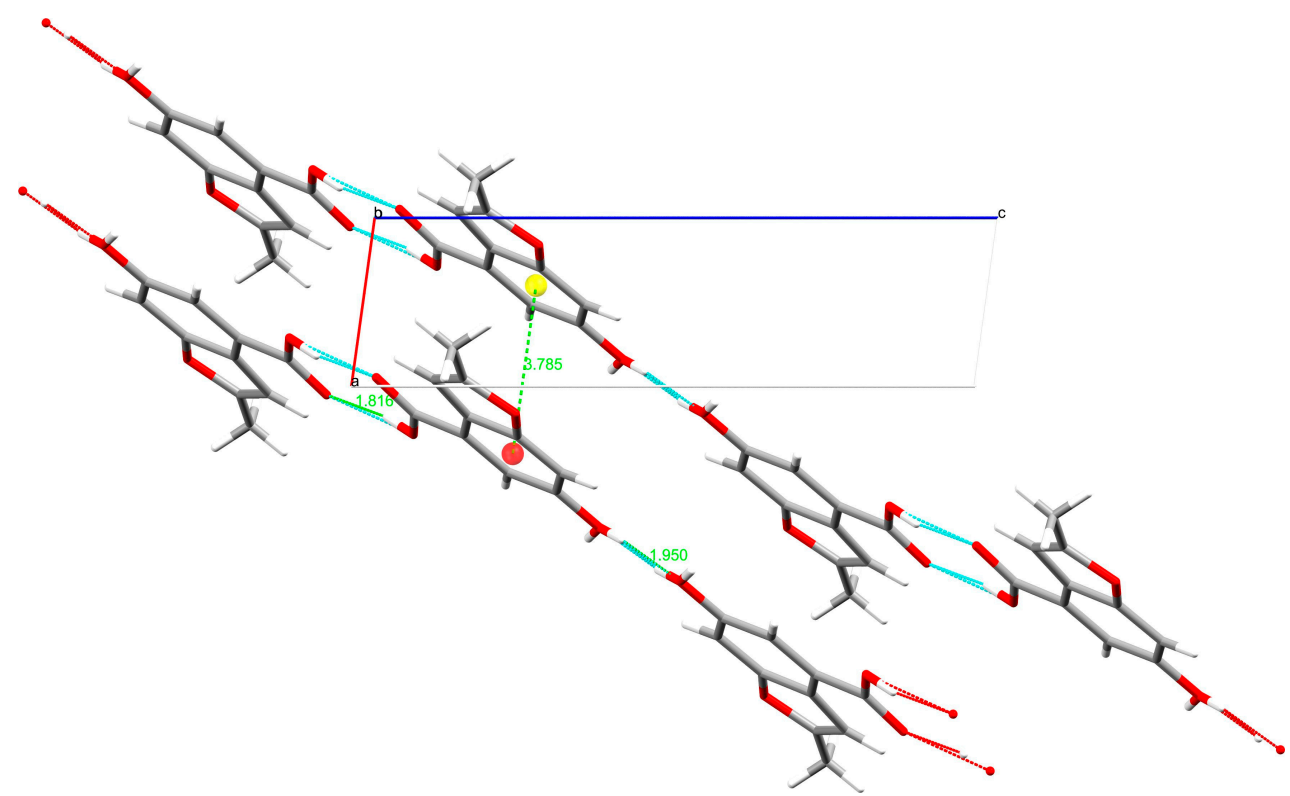

Figure 3. Crystal packing of $\mathbf{1}$, viewed along the $b$ axis. The dashed lines show the intermolecular contacts of the compound, while the colored spheres represent the centroids of the rings.

A summary of the H-bonds established within the crystal structure is reported in Table 1, along with a complete account of their geometry, as calculated by PARST [15].

Table 1. Hydrogen-bond geometry of $\mathbf{1}$ (arbitrary atom-numbering scheme used in Figure 2).

\begin{tabular}{|c|c|c|c|}
\hline H-Bond & 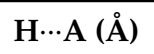 & 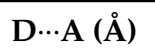 & D-H $\cdots A\left({ }^{\circ}\right)$ \\
\hline $\mathrm{O} 3-\mathrm{H} 3 \cdots \mathrm{O} 2$ & $1.82(1)$ & $2.623(1)$ & $167.8(1)$ \\
\hline $\mathrm{O} 4-\mathrm{H} 42 \cdots \mathrm{O} 4$ & $1.95(1)$ & $2.745(1)$ & $165.4(1)$ \\
\hline
\end{tabular}

The activity of the synthesized compounds was tested against the recombinant MbtI, as previously reported [9]. As expected from our previous data, the ester (2) showed a poor activity (\% residual enzymatic activity at $100 \mu \mathrm{M}: 82.5 \pm 11.1)$, while the free acid (1) exhibited a promising inhibitory effect (\% residual enzymatic activity at $100 \mu \mathrm{M}$ : $34.5 \pm 10.1$ ). Hence, the $\mathrm{IC}_{50}$ value of 1 was calculated to be $51.9 \pm 10.1 \mu \mathrm{M}$, revealing a comparable activity to that of our previous chromane-based lead, I.

\section{Materials and Methods}

\subsection{Synthesis}

All reagents and solvents were purchased from Sigma-Aldrich (St. Louis, MO, USA). All the reactions involving air-sensitive reagents were carried out using anhydrous solvents, in oven-dried glassware and under nitrogen atmosphere. Melting points were recorded on a Buchi M-565 apparatus (Buchi, Flawil, Switzerland), and are uncorrected. 
NMR spectra were recorded at room temperature either on a Varian Mercury (Varian, Palo Alto, CA, USA), equipped with an Oxford $300 \mathrm{MHz}$ cryomagnet (Oxford Instruments, Abingdon, UK), operating at $300 \mathrm{MHz}$ for ${ }^{1} \mathrm{H}$ analyses, or on a Bruker Avance 500 (Bruker, Billerica, MA, USA), operating at $500 \mathrm{MHz}$. DMSO- $d_{6}$ was used as deuterated solvent for all acquisitions. Chemicals shifts are expressed in ppm ( $\delta$ ) from tetramethylsilane resonance in the indicated solvent; coupling constants ( $J$-values) are given in Hertz $(\mathrm{Hz}) .{ }^{1} \mathrm{H}$ data are reported in the following order: ppm, multiplicity (s, singlet; $\mathrm{d}$, doublet; $\mathrm{t}$, triplet; $\mathrm{q}$, quartet; $\mathrm{m}$, multiplet), number of protons and attribution. The APT sequence was used to distinguish methyl and methine signals from those due to methylene and quaternary carbons.

For FT-IR analyses, compounds were mixed in 1:100 $w / w$ ratio with $\mathrm{KBr}$ and pressed through a hydraulic press (14 tons) to small tablets; data were recorded on a PerkinElmer SPECTRUM ONE instrument (PerkinElmer, Waltham, MA, USA), in the region between 4000 and $450 \mathrm{~cm}^{-1}$, performing 8 scans at $4 \mathrm{~cm}^{-1}$ resolution.

Mass Spectrometry analyses were carried out on a Thermo Finnigan LCQ Advantage (Thermo Fisher Scientific, Waltham, MA, USA), equipped with an ESI electrospray ionization source and an Ion Trap mass analyzer; ionization: ESI positive or ESI negative; capillary temperature: $250{ }^{\circ} \mathrm{C}$; source voltage: $5.50 \mathrm{kV}$; source current: $4.00 \mu \mathrm{A}$; multipole 1 and 2 offset: $-5.50 \mathrm{~V}$ and $-7.50 \mathrm{~V}$, respectively; intermultipole lens voltage: $-16.00 \mathrm{~V}$; trap DC offset voltage: $-10.00 \mathrm{~V}$.

NMR, FT-IR, and MS spectra of the synthesized compounds are provided in the Supplementary Materials.

\subsubsection{6-Hydroxy-2-methylbenzofuran-4-carboxylic Acid Methyl Ester (2)}

Propargyl bromide $(0.43 \mathrm{~mL}, 4.76 \mathrm{mmol})$, anhydrous $\mathrm{K}_{2} \mathrm{CO}_{3}(1.65 \mathrm{~g} .11 .90 \mathrm{mmol}), \mathrm{KI}(1.68 \mathrm{~g}$, $10.12 \mathrm{mmol})$ and $\mathrm{CuI}(0.03 \mathrm{~g}, 0.18 \mathrm{mmol})$ were added under nitrogen atmosphere to a solution of 3,5-dihydroxybenzoate $(1.00 \mathrm{~g}, 5.95 \mathrm{mmol})$ in dry DMF $(4 \mathrm{~mL})$, and the mixture was heated at $75^{\circ} \mathrm{C}$ for $24 \mathrm{~h}$. The residue obtained by the evaporation in vacuum of DMF was poured in ice-water and then extracted with ethyl acetate $(3 \times 10 \mathrm{~mL})$. The combined organic layers were dried over $\mathrm{Na}_{2} \mathrm{SO}_{4}$ and evaporated under reduced pressure; the crude residue was purified by column chromatography (silica gel ratio 1:60), using hexane/ethyl acetate (8:2 to 7:3), to afford compound 2 as a pale yellow solid (yield: $47 \%$ ). $\mathrm{R}_{\mathrm{f}}=0.32$ (hexane/EtOAc 8:2). M.p.: $140-142{ }^{\circ} \mathrm{C} .{ }^{1} \mathrm{H}-\mathrm{NMR}$ (300 MHz, DMSO): $\delta 9.75$ ( $\mathrm{s}$ exch $\left.\mathrm{D}_{2} \mathrm{O}, 1 \mathrm{H}, \mathrm{OH}\right), 7.33\left(\mathrm{~d}, J=2.2 \mathrm{~Hz}, 1 \mathrm{H}, \mathrm{H}_{5}\right), 7.14\left(\mathrm{dd}, J=2.2,0.9 \mathrm{~Hz}, 1 \mathrm{H}, \mathrm{H}_{7}\right), 6.86-6.80(\mathrm{~m}, 1 \mathrm{H}$, $\left.\mathrm{H}_{3}\right), 3.88$ (s, 3H, $\left.\mathrm{COOCH}_{3}\right), 2.42$ (s, 3H, $\mathrm{CH}_{3}$ ) ppm. ${ }^{13} \mathrm{C}-\mathrm{NMR}$ (75 MHz, DMSO): $\delta 187.61,166.86,156.64$, 156.46, 154.87, 122.31, 121.68, 113.64, 104.10, 103.41, 52.79, 14.51 ppm. FT-IR (KBr): v 3405, 3091, 2957, 2919, 2849, 1697, 1623, 1605, 1513, 1441, 1424, 1127, $999 \mathrm{~cm}^{-1}$. ESI-MS (m/z): calcd. for $\mathrm{C}_{11} \mathrm{H}_{10} \mathrm{O}_{4} 206,06$, found $205.12 \mathrm{~m} / \mathrm{z}[\mathrm{M}-\mathrm{H}]^{-}$.

\subsubsection{6-Hydroxy-2-methylbenzofuran-4-carboxylic Acid (1)}

A solution of powdered $\mathrm{NaOH}(30 \mathrm{mg}, 0.75 \mathrm{mmol})$ in water $(1 \mathrm{~mL})$ and methanol $(0.4 \mathrm{~mL})$ was added to compound $2(70 \mathrm{mg}, 0.34 \mathrm{mmol})$. The reaction mixture was stirred at $55^{\circ} \mathrm{C}$ for $6 \mathrm{~h}$ and then partially concentrated in vacuum to remove methanol. The $\mathrm{pH}$ of the solution was adjusted to $\mathrm{pH} 3-4$ by the addition of a few drops of $1 \mathrm{M} \mathrm{HCl}$, thereby inducing the precipitation of the free acid 1, which was collected by filtration as a white solid (yield: $50 \%$ ). $\mathrm{R}_{\mathrm{f}}=0.1$ (EtOAc/MeOH 8:2). M.p.: $208-210{ }^{\circ} \mathrm{C}$. ${ }^{1} \mathrm{H}-\mathrm{NMR}$ (300 MHz, DMSO): $\delta 12.88$ (s exch $\left.\mathrm{D}_{2} \mathrm{O}, 1 \mathrm{H}, \mathrm{COOH}\right), 9.67$ (s exch $\left.\mathrm{D}_{2} \mathrm{O}, 1 \mathrm{H}, \mathrm{OH}\right), 7.28(\mathrm{~d}$, $\left.J=2.2 \mathrm{~Hz}, 1 \mathrm{H}, \mathrm{H}_{5}\right), 7.07\left(\mathrm{~d}, J=2.2, \mathrm{~Hz}, 1 \mathrm{H}, \mathrm{H}_{7}\right), 6.80\left(\mathrm{~s}, 1 \mathrm{H}, \mathrm{H}_{3}\right), 2.39\left(\mathrm{~s}, 3 \mathrm{H}, \mathrm{CH}_{3}\right) \mathrm{ppm} .{ }^{13} \mathrm{C}-\mathrm{NMR}$ (75 MHz, DMSO): $\delta$ 167.59, 156.04, 155.81, 154.38, 122.57, 122.07, 113.49, 103.88, 102.52, 14.08 ppm. FT-IR (KBr): 3281, 3077, 2962, 2919, 2848,1690, 1626, 1600, 1496, 1439, 1392, $1127 \mathrm{~cm}^{-1}$. ESI-MS (m/z): calcd. for $\mathrm{C}_{10} \mathrm{H}_{8} \mathrm{O}_{4} 192.17$, found $191.41 \mathrm{~m} / \mathrm{z}[\mathrm{M}-\mathrm{H}]^{-}$. 


\subsection{Single-Crystal X-ray Diffraction}

The slow evaporation of a methanol/water 1:1 solution of 1 afforded diffraction-quality yellow laminar crystals, after about one week at room temperature.

Crystallographic data for $\mathbf{1}$ were collected at ambient temperature on a Bruker-Axs CCD-based three-circle diffractometer, using graphite-monochromatized Mo-Ka X-radiation $(\lambda=0.7107 \AA)$.

$X$-ray diffraction data in the $\theta$ range $2^{\circ}-25^{\circ}$ were collected by acquiring four sets of 600 bidimensional CCD frames with the following operative conditions: omega rotation axis; scan width: $0.3^{\circ}$; acquisition time: $20 \mathrm{~s}$; sample-to-detector distance: $60 \mathrm{~mm} ; \varphi$ angle: fixed at four different values $\left(0^{\circ}, 90^{\circ}, 180^{\circ}, 270^{\circ}\right)$ for the four different sets. Omega-rotation frames were processed with SAINT [16] for data reduction (including intensity integration, background, Lorentz and polarization corrections) and for the determination of accurate unit-cell dimensions, obtained by least-squares refinement of the positions of 1359 independent reflections with $\mathrm{I}>10 \sigma(\mathrm{I})$ in the $\theta$ range $2^{\circ}-24^{\circ}$. Absorption effects were empirically evaluated with the SADABS software [17], and absorption correction was applied to the data ( 0.874 and 0.994 as min and max transmission factor, respectively).

The structures were solved by direct methods using SIR-14 [18] and completed by iterative cycles of full-matrix least-squares refinement on $\mathrm{F}_{0}{ }^{2}$ and DF synthesis using SHELXL-17 [19] on the WingX.v2014.1 suite [20]. Hydrogen atoms bonded to carbons were included at geometrically calculated positions and refined using a riding model. The contribution of disordered solvent molecules, embedded in the crystal, to the calculated structure factors was determined with PLATON SQUEEZE [21], and included in the final steps of the refinement. Graphical representations were rendered with Mercury 4.3.1 [22]. CCDC entry 2004172 contains the supplementary crystallographic data for this paper. These data can be obtained free of charge via http://www.ccdc.cam.ac.uk/conts/retrieving.html (or from the CCDC, 12 Union Road, Cambridge CB2 1EZ, UK; Fax: +44 1223 336033; E-mail: deposit@ccdc.cam.ac.uk).

Crystal data for compound 1: $\mathrm{C}_{10} \mathrm{H}_{8} \mathrm{O}_{4}, M_{\mathrm{r}}=192.16 \mathrm{~g} / \mathrm{mol}$, Triclinic, Space group $P-1, a=3.7850(6)$ $\AA, b=10.1380(16) \AA, c=14.416(2) \AA, \alpha=104.780(2)^{\circ}, \beta=94.920(2)^{\circ}, \gamma=100.720(2)^{\circ}, V=520.35(14)$ $\AA^{3}, Z=2, D_{\text {calc }}=1.226 \mathrm{Mg} / \mathrm{m}^{3}, \mathrm{~F}(000)=200, R=0.057$ for 1383 reflections with $F o>4 \operatorname{sig}(F o)$ ( $R=0.073$ for all 1842 unique/4979 collected reflections), $w R 2=0.172$ for reflections with $F o>4 \operatorname{sig}(F o)$ $(w R 2=0.186$ for all unique reflections), $T=293(2) \mathrm{K}, G O F=1.084$. The reflections were collected in the range $1.475^{\circ} \leq \theta \leq 25.043^{\circ}$ (limiting indices $=-4 \leq \mathrm{h} \leq 4,-12 \leq \mathrm{k} \leq 12,-17 \leq 1 \leq 17$ ) employing a $0.26 \times 0.15 \times 0.06 \mathrm{~mm}$ crystal. The residual positive and negative electron densities in the final map were 0.214 and $-0.133 \AA^{-3}$.

\subsection{Enzymatic Assays}

Recombinant M. tuberculosis MbtI was produced and purified as previously reported [8,9]. Enzyme activity was determined by measuring the production of salicylic acid through a fluorimetric assay, slightly modified from Vasan et al. [23]. The tests were performed at $37^{\circ} \mathrm{C}$ in a final volume of $400 \mu \mathrm{L}$ of $50 \mathrm{mM}$ Hepes pH 7.5, $5 \mathrm{mM} \mathrm{MgCl}_{2}$, using 1-2 $\mu \mathrm{M} \mathrm{MbtI}$; the reactions were started by the addition of chorismic acid and monitored using a PerkinElmer LS3 fluorimeter (Ex. $\lambda=305 \mathrm{~nm}, \mathrm{Em} . \lambda=420 \mathrm{~nm}$ ). Residual enzymatic activity was calculated in the presence of the compound at $100 \mu \mathrm{M}$ (stock solution $20 \mathrm{mM}$ in DMSO) and $50 \mu \mathrm{M}$ chorismic acid. $\mathrm{IC}_{50}$ was determined by measuring enzyme activity at different compound concentrations, and fitting data to the equation:

$$
\mathrm{A}_{[\mathrm{I}]}=\mathrm{A}_{[0]} \times\left(1-\frac{[\mathrm{I}]}{[\mathrm{I}]+\mathrm{IC}_{50}}\right)
$$

where $A_{[I]}$ is the activity of the enzyme at inhibitor concentration $[\mathrm{I}]$ and $\mathrm{A}_{[0]}$ is the activity of the enzyme without inhibitor. 
Supplementary Materials: The following are available online: http://www.mdpi.com/1422-8599/2020/2/M1143/s1 Figure S1: ${ }^{1} \mathrm{H}-\mathrm{NMR}$ spectrum of 6-hydroxy-2-methylbenzofuran-4-carboxylic acid methyl ester (2), Figure S2: ${ }^{13}$ C-NMR spectrum of methyl ester (2), Figure S3: COSY spectrum of methyl ester (2), Figure S4: NOESY spectrum of methyl ester (2), Figure S5: HSQC spectrum of methyl ester (2), Figure S6: HMBC spectrum of methyl ester (2), Figure S7: FT-IR spectrum of methyl ester (2), Figure S8: ESI-MS spectrum of methyl ester (2), Figure S9: ${ }^{1} \mathrm{H}-\mathrm{NMR}$ spectrum of 6-hydroxy-2-methylbenzofuran-4-carboxylic acid (1), Figure S10: ${ }^{13} \mathrm{C}-\mathrm{NMR}$ spectrum of acid (1), Figure S11: FT-IR spectrum of acid (1), Figure S12: ESI-MS spectrum of acid (1).

Author Contributions: Synthesis: A.D., G.C.; NMR data analysis: E.P., D.N.; Crystal analysis: F.M., M.M. Enzymatic assays: L.R.C.; Writing—original draft preparation: A.G., E.P.; Writing—review and editing: E.P., S.V.; Supervision and project administration: E.P., S.V. All authors read and approved the final manuscript.

Funding: The work was financially supported by the University of Milan (Linea B) and the University of Pavia.

Conflicts of Interest: The authors declare no conflict of interest.

\section{References}

1. Global Tuberculosis Report 2019; World Health Organization: Geneva, Switzerland, 2019; ISBN 9789241565646.

2. Sotgiu, G.; Centis, R.; D'Ambrosio, L.; Migliori, G.B. Tuberculosis treatment and drug regimens. Cold Spring Harb. Perspect. Med. 2015, 5, a017822. [CrossRef] [PubMed]

3. Chiarelli, L.R.; Mori, G.; Esposito, M.; Orena, B.S.; Pasca, M.R. New and old hot drug targets in tuberculosis. Curr. Med. Chem. 2016, 23, 3813-3846. [CrossRef]

4. Fanzani, L.; Porta, F.; Meneghetti, F.; Villa, S.; Gelain, A.; Lucarelli, A.P.; Parisini, E. Mycobacterium tuberculosis low molecular weight phosphatases (MPtpA and MPtpB): From biological insight to inhibitors. Curr. Med. Chem. 2015, 22, 3110-3132. [CrossRef]

5. Mori, M.; Sammartino, J.C.; Costantino, L.; Gelain, A.; Meneghetti, F.; Villa, S.; Chiarelli, L.R. An overview on the potential antimycobacterial agents targeting serine/threonine protein kinases from Mycobacterium tuberculosis. Curr. Top. Med. Chem. 2019, 19, 646-661. [CrossRef] [PubMed]

6. Truzzi, E.; Meneghetti, F.; Mori, M.; Costantino, L.; Iannuccelli, V.; Maretti, E.; Domenici, F.; Castellano, C.; Rogers, S.; Capocefalo, A.; et al. Drugs/lamellae interface influences the inner structure of double-loaded liposomes for inhaled anti-TB therapy: An in-depth small-angle neutron scattering investigation. J. Colloid Interface Sci. 2019, 541, 399-406. [CrossRef] [PubMed]

7. Meneghetti, F.; Villa, S.; Gelain, A.; Barlocco, D.; Chiarelli, L.R.; Pasca, M.R.; Costantino, L. Iron acquisition pathways as targets for antitubercular drugs. Curr. Med. Chem. 2016, 23, 4009-4026. [CrossRef]

8. Chiarelli, L.R.; Mori, M.; Barlocco, D.; Beretta, G.; Gelain, A.; Pini, E.; Porcino, M.; Mori, G.; Stelitano, G.; Costantino, L.; et al. Discovery and development of novel salicylate synthase (MbtI) furanic inhibitors as antitubercular agents. Eur. J. Med. Chem. 2018, 155, 754-763. [CrossRef] [PubMed]

9. Chiarelli, L.R.; Mori, M.; Beretta, G.; Gelain, A.; Pini, E.; Sammartino, J.C.; Stelitano, G.; Barlocco, D.; Costantino, L.; Lapillo, M.; et al. New insight into structure-activity of furan-based salicylate synthase (MbtI) inhibitors as potential antitubercular agents. J. Enzyme Inhib. Med. Chem. 2019, 34, 823-828. [CrossRef]

10. Mori, M.; Stelitano, G.; Gelain, A.; Pini, E.; Chiarelli, L.R.; Sammartino, J.C.; Poli, G.; Tuccinardi, T.; Beretta, G.; Porta, A.; et al. Shedding X-ray light on the role of magnesium in the activity of M. tuberculosis salicylate synthase (MbtI) for drug design. J. Med. Chem. 2020. [CrossRef]

11. Pini, E.; Poli, G.; Tuccinardi, T.; Chiarelli, L.; Mori, M.; Gelain, A.; Costantino, L.; Villa, S.; Meneghetti, F.; Barlocco, D. New chromane-based derivatives as inhibitors of Mycobacterium tuberculosis Salicylate Synthase (MbtI): Preliminary biological evaluation and molecular modeling studies. Molecules 2018, 23, 1506. [CrossRef]

12. Palisse, A.; Kirsch, S.F. Synthesis of furans through silver-catalyzed propargyl-Claisen rearrangement followed by cyclocondensation. Eur. J. Org. Chem. 2014, 2014, 7095-7098. [CrossRef]

13. More, K.R. Review on synthetic routes for synthesis of benzofuran-based compounds. J. Chem. Pharm. Res. 2017, 9, 210-220.

14. Farrugia, L.J. ORTEP-3 for Windows-A version of ORTEP-III with a graphical user interface (GUI). J. Appl. Crystallogr. 1997, 30, 565. [CrossRef]

15. Nardelli, M. PARST 95-An update to PARST: A system of Fortran routines for calculating molecular structure parameters from the results of crystal structure analyses. J. Appl. Crystallogr. 1995, 28, 659. [CrossRef]

16. SMART \& SAINT Software Reference Manual; Version 6.45; Bruker AXS, Inc.: Madison, WI, USA, 2003. 
17. Krause, L.; Herbst-Irmer, R.; Sheldrick, G.M.; Stalke, D. Comparison of silver and molybdenum microfocus X-ray sources for single-crystal structure determination. J. Appl. Crystallogr. 2015, 48, 3-10. [CrossRef] [PubMed]

18. Burla, M.C.; Caliandro, R.; Carrozzini, B.; Cascarano, G.L.; Cuocci, C.; Giacovazzo, C.; Mallamo, M.; Mazzone, A.; Polidori, G. Crystal structure determination and refinement via SIR2014. J. Appl. Crystallogr. 2015, 48, 306-309. [CrossRef]

19. Sheldrick, G.M. Crystal structure refinement with SHELXL. Acta Crystallogr. Sect. C Struct. Chem. 2015, 71, 3-8. [CrossRef]

20. Farrugia, L.J. WinGX and ORTEP for Windows: An update. J. Appl. Crystallogr. 2012, 45, 849-854. [CrossRef]

21. Spek, A.L. PLATON SQUEEZE: A tool for the calculation of the disordered solvent contribution to the calculated structure factors. Acta Crystallogr. Sect. C Struct. Chem. 2015, 71, 9-18. [CrossRef]

22. MacRae, C.F.; Sovago, I.; Cottrell, S.J.; Galek, P.T.A.; McCabe, P.; Pidcock, E.; Platings, M.; Shields, G.P.; Stevens, J.S.; Towler, M.; et al. Mercury 4.0: From visualization to analysis, design and prediction. J. Appl. Crystallogr. 2020, 53, 226-235. [CrossRef]

23. Vasan, M.; Neres, J.; Williams, J.; Wilson, D.J.; Teitelbaum, A.M.; Remmel, R.P.; Aldrich, C.C. Inhibitors of the Salicylate Synthase (MbtI) from Mycobacterium tuberculosis Discovered by High-Throughput Screening. ChemMedChem 2010, 5, 2079-2087. [CrossRef] [PubMed]

(C) 2020 by the authors. Licensee MDPI, Basel, Switzerland. This article is an open access article distributed under the terms and conditions of the Creative Commons Attribution (CC BY) license (http://creativecommons.org/licenses/by/4.0/). 